\title{
Environmental Issues in a Trade War: a Political Economy Perspective
}

\author{
Husnul Isa Harahap \\ Department of Political Science \\ University of North Sumatra \\ Medan, Indonesia \\ husnul.harahap@usu.ac.id
}

\begin{abstract}
A trade war is a conflict that occurs between two or more countries in the sector of trade. The conflict can be seen in the case of an increase in tariffs or other obstacles made to disrupt the economic balance of a country, so that the country changes its economic policy or trade. One issue in trade wars involves environmental matters. What are they? The findings of this study indicate that there are three main environmental issues in a trade war: environmental harm, health standards on traded products, and human rights issues. The study also found that there were typically double standards in trade political policies that were suggestive of trade wars. This study recommends that it is very necessary to build a world dialogue forum, to formulate environmental problems and economic interests.
\end{abstract}

Keywords - trade war, environmental, political policy, double standards, national interest.

\section{INTRODUCTION}

Entering the era of globalization in the early 2000s, nearly every country cooperated with other countries. Each country attempted to establish relationships with other countries, and even create communities. This phenomenon is known as Complex Interdependence, coined by Djamel Eddine Laoisset [1, p. 660]. Relations between countries are largely formed due to the equality of perspectives and interests, especially regarding trade.

Stefan Fritsch notes that in the perspective of International Political Economy theory, trade is the arena of play [1, p. 669] and is globally mutually beneficial among many parties. Data specifies that the vision of world trade with the theme of globalization has had an impact on increasing trade that is growing rapidly. The value of world trade has increased 65 times when compared to the post-World War II period of the 1960s [1, p. 677]

War is one of the factors that inhibits the growth of world trade. Both the Merriam-Webster Dictionary and Stanford Encyclopedia of Philosophy consider war as conflict, and Carl von Clausewitz views war as coercion of the will [2]. War is related to the use of combat equipment and causes world instability, even threatening human safety.

In 2018, international media used the term "trade wars" to refer to the act of imposing a high tariff on a product imported by a country. For example, Bloomberg Media Group put out an article with the title "Trump Wanted a Trade War. Here's What One Looks Like." Bloomberg defines a trade war as "an economic conflict between countries that import restrictions on each other in order to harm each other's trade" [3].
Essentially, there are many other cases similar to the case reported by Bloomberg. What is interesting is the increase in import tariffs or other actions related to trade war that are not independent. That is, there are always issues that form the basis of the authorities in a country to make that decision. In the context of a trade war between the United States and China, there are several issues to address, including technology licensing, government subsidies to support the domestic industry, complicated licensing, and environmental issues.

Environmental issues are one of the bases of reference for policymaking in a country in order to change its trade policies in other countries. As a result, countries affected by the policy will have problems with exporting their products. This issue is one that is often encountered by developing countries in trade. This article will discuss the environmental issues in a trade war.

\section{METHODOLOGY}

This study uses the political ecological and political economy approaches, as well as collection data by using library resources and the Internet. James B. Greenberg and Thomas K. Park described "Political ecology ... is a historical outgrowth ... about the relations between human society, viewed in its bio-cultural-political complexity, and a significantly humanized nature" $[4$, p. 1$]$

Allan Drazen defined political economy "is the study of the interaction of politics and economics ... It is defined in large part by its use of the formal and technical tools of modern economic analysis to look at the importance of politics for economics" [5, p. 5]. It's because political factors are crucial in determining economic outcomes [5].

The trade war referred to in this study is not limited to the trade war between the United States and China. The analysis in this study uses an analysis of political economy and political ecology.

\section{ThreE MAIN Issues: CONSISTENCY TEST}

Environmental issues are those that often arise in the topic of 20th century trade. This is inseparable from the existence of alarming natural symptoms such as global warming, rise in sea level, air pollution, and others. Initially, all of this was considered to be an impact on development. However, countries finally began to realize that world trade also had an impact on environmental impairment. The link between world trade and environmental damage occurs when countries all over the world increase production without limits, subjecting the environment to harm. 
The World Environment Day, which just passed on June 5,2019 , is proof of the world's concern for the environment [6]. In addition, there are many international agreements in place to address environmental damage problems, such as the Vienna Convention (1985), Montreal Protocol (1987, 1990, 1992), UN-FCCC (1992), Kyoto Protocol (1997), Marrakech Agreement (2001), and Bali Road Map (2007) [7, p. 32].

Environmental problems and free trade are also closelyrelated matters. Some nations even use environmental issues to strengthen their bargaining position with other countries. Cases like this are real examples of how environmental problems have become an integral part of the subject of trade war.

In general, there are three environmental issues related to trade war. The first is the issue of environmental harm, which most often appears in trade wars. The most recent case was when the European Commission concluded that oil palm plantations had caused massive deforestation [8].

According to a Reuters report in the results of the 2008 European Commission study, $45 \%$ of the expansion in CPO production was caused by forest destruction. CPO competitors, namely soybean oil and sunflower, have a lower record. Each is $8 \%$ and $1 \%$ of the expansion of production of this commodity [9].

In January 2019, Saifuddin Abdullah's Malaysian foreign affairs minister said, "Malaysia is committed to producing sustainable palm oil ... every drop of palm oil produced in Malaysia will be certified sustainable by 2020." [10]

According to Elizabeth Robinson and Harry Purnomo, palm oil-importing countries can establish other policies to reduce the use of palm oil. Its purpose is to provide incentives so that people buy electric cars [11]. Therefore, proenvironmental policies should not always be identical with the pressure on countries that are considered unable to maintain the environment effectively.

A trade war that involves environmental issues is indeed very complicated. According to Anna Yulia Hartati, this creates a dilemma between prioritizing economic or environmental interests [12, p. 198]. However, the actual burden of environmental issues will not be effective if managed by one party.

The effort to replace palm oil with soybean oil and sunflower also raises the questions: Is it really because of environmental problems or because there are other issues that are becoming a factor, such as changes in the world soybean export market? The European market as a new target in terms of the soybean business is the result of a world trade war in which each European country calculates the profit and loss of ignoring the soybeans from the aspect of its economic political interests.

According to Azky Muhammad Aryaraja, a country like the United States (1996-2001) has an average of 72 million tons of soybean production, 31 million tons of which must be exported [13, p. 4]. The Food Security Portal data illustrates that in 2016, the number that was successfully exported increased to 57.7 million tons [14].

Moreover, the Observatory of Economic Complexity's data indicates that China is an importer of 63 percent of soybeans in the world, and the European Union imports less than 5 percent [15]. The data also substantiates that there is a connection between the trade war of the United States and China with the possibility of plans to switch the soybean market from China to Europe.

Based on the market change scenario due to trade war, it can be analyzed that EU policy is a form of protectionism [16] in an effort to protect the domestic economy. Protectionism influences trade patterns [17]. If there is a relationship of inconsistencies faced of the environmental issues with the existence of EU import product change policies, it can be said that the context of protectionism is to safeguard political economic interests.

An Okezone.com report states that in 2019, European countries also bought more soybeans than usual last year in the midst of a trade deadlock between the United States and China, and an increase in local soybean oil production could reduce the import needs of vegetable oils as a whole, especially palm oil [18].

In this case, the European Union avoids a trade war with the United States. If this analysis is correct, then the country producing palm oil will be forced to face the domino effect of the wave of world trade war under the pretext of environmental issues.

The second issue is that of health standards on traded products. This issue also has much to do with palm oil. Independent online media reports that "when it comes to cooking oils, palm oil is typically considered the most controversial of options - for both health and environmental reasons" [19].

The third issue involves human rights. Media Theory online media said that "the ongoing trade war between the two countries presents a new opportunity for Washington to expose a condition and hopefully resolves the human rights violations in China" [20]. This issue is one that has not long emerged in international relations between the United States and China. Most human rights issues are related to an arms embargo.

Indonesia's situation was very different; they experienced pressure in the form of an embargo (1995 to 2005) due to cases of alleged human rights violations in Dili, East Timor (1991) [21], and China suffered an embargo for buying weapons from Russia. The sanction of an embargo can be understood as playing a part in the political pressure on a country. The United States requires countries that buy weapons from Russia to be sanctioned by an embargo from the United States because Russia is considered the cause of the crisis in Ukraine. Thus, there seems to be a consistent motive for the issue of human rights in the context of an arms embargo as part of a trade war. But this consistency still needs to be tested, according to a statement made by the President of the United States, that not all countries will receive sanctions [22].

As of the writing of this article, the most recent case related to the issue of human rights was the trade war between Japan and South Korea. Japan reduced material exports to make smart phone components for South Korea. This trade policy was carried out by Japan because South Korea raised the issue of human rights violations in World War II involving Japan. The Korea Times stated "Korea's Supreme Court ruled last year, Japanese companies, including Mitsubishi, must pay 
compensation to individual Korean victims forced to work in their factories before and during World War II" [23].

The trade war between Japan and South Korea is quite unique because it departs from sensitive but unexpected problems. It is unimaginable to be the cause of a trade war between Japan and South Korea because these two countries are mutually reinforcing countries from the trade side, and are also neighboring countries.

\section{ECONOMICS OR ECOLOGY, INTERCHANGEABLE INTERESTS?}

Laura Buffet (Clean Transport Manager at the NGO Transport \& Environment) said, "This is only a partial victory since soy and some palm oil can still be labeled green," [24]. This statement affirms that if you want to be consistent with environmental issues, all products that have an impact on environmental damage are not differentiated from ones that also cause damage. This means that changes in a country's commodity trade import policy will cause controversy if it raises environmental reasons as the basis of the policy.

In fact, if you want to have environmental issues be a part of the issue of the world of commerce, you must focus on concrete and objective issues. For example, involving an independent group of experts to conduct studies or map problems for a product or commodity, and their impact on the environment. No less important is finding a solution if it turns out that there are environmental problems in the product or commodity. This is based on the assumption that each country can improve its commitment to the environment.

Is field supervision needed? If it is, supervision can be a solution to the problem of forest destruction. Also, relevant countries can calculate the effective amount of land that is directly related to commodity production, and make new forests in areas that have the potential to become forests. The principle is how to improve environmental commitment by increasing the participation of all of the countries in the world.

The political economy approach can complement the political ecology approach. In a political economy perspective, one way to balance adverse policies is to renegotiate in order to preserve greater interests rather than being trapped in the trade war itself, which has an impact on the worsening of state relations. Consequently, trade missions can be accomplished while strengthening the commitment to improve the damaged environment.

\section{CONCLUSION}

Trade war is a phenomenon that is not new in the practice of world trade. The problem is, in the era of globalization or free markets, all countries have trade relations directly or indirectly affecting the world trade and business networks. Hence, trade war in the context of free trade, in relation to trade war with environmental issues, is actually a new phenomenon.

Environmental issues are one of the instruments used in a trade war to place a country in a situation that is cornered in the world of commerce so that it deserves a policy that is detrimental to the country. This article analyzes three main environmental issues in a trade war: environmental harm, health standards on traded products, and human rights issues. Among the three issues, it seems that the problem of environmental damage has a clearer impact on the subject of trade wars, which have an impact on the economic problems of a country. Meanwhile, the human rights issue has distanced itself from environmental issues. The arms embargo, which has both a direct and indirect impact on human rights, has a correlation with security politics.

\section{REFERENCES}

[1] J. T. Ishiyama and M. Breuning, Ilmu Politik dalam Paradigma Abad 21, 1st ed. Jakarta: Kencana Prenada Media Group, 2013.

[2] J. Long, "What is War? A New Point of View," Small Wars Journal.

[3] A. Mayeda and B. Baschuk, "Trump Wanted a Trade War. Here's What One Looks Like,” Bloomberg.com, Mar. 2018.

[4] J. B. Greenberg and T. K. Park, "Political Ecology," J. Polit. Ecol., vol. 1, pp. 1-12, 1994.

[5] A. Drazen, Political Economy in Macroeconomics. Princeton: Princeton University Press, 2000.

[6] R. Rahmat, "Sejarah Terbentuknya Hari Lingkungan Hidup Sedunia," Environment Indonesia Center, 05-Jun-2015.

[7] S. Wijoyo, "Dinamika Komitmen Internasional dalam Kerangka Pengendalian Global Warming," Kanun J. Ilmu Huk., vol. 56, no. XIV, pp. 13-35, Apr. 2012.

[8] E. Krukowska, "EU Sets Limits on Palm Oil in Biofuels as Trade War Looms,” Bloomberg.com, 13-Mar-2019.

[9] R. Satrianegara and S. Pablo, "UE Diskriminasi CPO, Pemerintah RI Gelar Pertemuan Khusus," cnbcindonesia.com, 20-Mar-2019.

[10] S. Stefanini, "EU set to tighten rules on palm oil for biofuels," climatechangenews.com, 02-Apr-2019.

[11] Elizabeth Robinson and H. Purnomo, "Palm oil: EU ban won't save Asian rainforests, but here's what might help," The Jakarta Post.com, 07-May-2019.

[12] A. Y. Hartati, "Lingkungan Hidup dan Liberalisasi Perdagangan: Upaya Mencari Jalan Tengah," Urnal Ilmu Sos. Dan Ilmu Polit., vol. 11, no. 2, pp. 153-286, Nov. 2007.

[13] A. M. Aryaraja, "Dominasi Amerika Serikat dalam Perdagangan Kedelai Impor Indonesia Tahun 1998-2000,” J. UNAIR, 2013.

[14] IFPRI, "Soybean Exports," The Food Security Portal.

[15] "Soybeans Trade," Observatory of Economic Complexity.

[16] R. A. D. Marsaulina, "Penolakan Crude Palm Oil (CPO) Indonesia oleh Uni Eropa," Skripsi Sarjana, Universitas Gadjah Mada, Yogyakarta, 2014

[17] A. I. Kurniawan, "Kebijakan Proteksionisme Uni Eropa dan Dampaknya Terhadap Ekspor Crude Palm Oil (CPO) Indonesia ke Eropa," Skripsi Sarjana, Universitas Pasundan, Fakultas Ilmu Sosial dan Ilmu Politik, 2018.

[18] O. W. lestari, "Sawit RI Didiskriminasi di Eropa, Ini Sederet Faktanya," okezone.com, 24-Mar-2019.

[19] C. Ritschel, "The reasons why palm oil is so controversial," 24-Aug2018

[20] B. Artman, "The Human Rights Dimension of Our Trade War with China," Media Theory, 10-Jul-2019.

[21] Muannas, "Pencairan Embargo Militer Amerika Terganjal Kasus Timor Timur," Tempo.co, Selasa, Agustus 09:46 WIB-2003.

[22] "Trump Tolak Sanksi bagi Arab Saudi," Kompas.com, 22-Nov2018.

[23] J. Ji-hye, "Korea, Japan heading toward trade war," The Korea Times, 13-Jul-2019.

[24] D. Keating, "EU Labels Biofuel from Palm Oil as Unsustainable, Bans Subsidies," forbes.com, 14-Mar-2019. 